\title{
EVALUATION OF CLCUV TOLERANCE IN COTTON (Gossypium hirsutum) VARIETIES BY DNA DETECTION
}

\author{
Aamir Sajjad 1,*, Muhammad Aslam Khan', Kashif Riaz ${ }^{1}$, Muhammad Mubin², Atif Shehzad \\ and Muhammad Azam ${ }^{3}$
}

\author{
${ }^{1}$ Department of Plant Pathology, University of Agriculture, Faisalabad, Pakistan; ${ }^{2}$ Center of Agricultural \\ Biochemistry and Biotechnology, University of Agriculture, Faisalabad, Pakistan; ${ }^{3}$ Department of Agronomy, \\ University of Agriculture, Faisalabad, Pakistan. \\ "Correspondence author's e-mail: as.manc@hotmail.co.uk
}

Cotton leaf curl virus (ClCuV) has the most damaging and rapidly evolving virus spp infecting cotton (Gossypium hirsutum L.) and make cotton leaf curl disease complex. CLCuD is caused by Bemicia tabaci transmitted monopartite begomovirus whose genome is composed of DNA-A and satellite components. Present study of cotton was designed to amplify the circular single stranded molecule of begomovirus associated with CLCuD through RCA technique. Twenty lines/varieties of cotton were evaluated for their response against cotton leaf curl virus. Total genomic DNA from these samples were isolated from cotton varieties/lines and full length viral DNA-A components from CLCuV infected cotton plants were polymerized through PCR by using universal begomo 01 and begomo 02 primers. Further insilico study of different viruses with restriction enzymes PstI and EcoRI was done. The residual viral titer which was evaluated through PCR, its value was compared with the visually observed symptoms to evaluate the plant response. All varieties showed disease symptoms of which susceptible varieties were FH-114. MNH-886, LALAZAR, MS-71, MS-289, FH-682, FH-900, Z-31, ALI AKBR-703, N-112. Moreover, moderate susceptible varieties were FH-942, FH-142, MNH-86, CM-595, HUMA-15, ALI AKBR-905. However, moderate resistant varieties were FH-941, CM-595, ALI AKBR-905, CA-12.

Keywords: Ascochyta blight, Geminiviridae, leaf enation, fragments.

\section{INTRODUCTION}

Cotton (Gossypium hirsutum L.) belonging to family Malvaceae, genus Gossypium contains four cultivated species of cotton named as Gossypium herbaceum, Gossypium hirsutum, Gossypium barbadense and Gossypium arboreum. Pakistan stands at $4^{\text {th }}$ position in terms of cotton production in the world by producing 2.08 million tons, after India 6.37 million tons and USA 2.80 million tons. Pakistan is the $3^{\text {rd }}$ biggest consumer (2.49 million tons) in the world after China and India. China is the biggest producer of cotton in the world with production of 6.7 million tons. Cotton (Gossypium hirsutum) known as "white gold" occupies a prominent position in agro-based economy of Pakistan being exported in multiple forms of commodities like raw cotton, yarn and value added textile and fabric products, also provides livelihood to a number of people engaged in textile industry (Farooq et al., 2011). Cotton is cultivated in 60 countries of the world including Pakistan and it provides means of employment for millions of farmers and workers. It provides not only fiber for textile industry but also edible oil for human consumption. In foreign exchange earnings, its contribution is $60 \%$ in exports of worth added products. During July-March, 2014-15 the agriculture development stood at 2.9 percent as compared to 2.7 percent during the last year. During 2014-15, total cotton production was 13,983 thousand bales as compared to 12,769 thousand bales in 2013-14 and noted an increase of 9.5 percent (GOP, 2015). Cotton seed oil is a good source of essential fatty acids. Cotton seed also contributes $4 \%$ to vegetable oil production throughout the world (Bruinsma, 2003).

Cotton diseases include fungal diseases, seedling diseases (Damping off, wilts and root rots), leaf spots, Ascochyta blight, boll rots, bacterial diseases, leaf blight/angular leaf spot, nematode disease, root knot nematode, viral diseases and cotton leaf curl virus disease. The virus is transportable genetic element, undoubtedly of cellular origin. Records suggest that there are a minimum of 10-100 viruses for microorganism, animal and plant. More than 1,000 diverse viruses can infect man. They most often affect the cells of host negatively, even kill them, and inescapably and repeatedly face problem of moving on and settling the new healthy hosts. Viruses can move from cell to cell and cover wide distances by vascular system within a single host (Norrby, 2008). Viruses are divided in two groups, DNA and RNA viruses. A very few viruses have DNA genome and mostly viruses have RNA genome. According to the latest classification, viruses are divided into three orders, 73 families, 9 subfamilies, 287 genera, 1950 species. Viruses are grouped according to shape and size, structure of the genome and chemical composition, 
and mode of replication. The genus Begomovirus name was derived from Bean golden yellow mosaic virus (Stanley et al., 2005). These begomoviruses are divided into two groups such as monopartite and bipartite this depends upon consist of their genomes such one or two ssDNA components. Most common begomoviruses between these two are bipartite which contains DNA-A and DNA-B both molecules. Size of both molecules ranging from 2.6 to $2.8 \mathrm{~kb}$, and these bidirectional transcribed (Seal et al., 2006).

Cotton Leaf Curl Virus (CLCuD) is main problem in cotton production and surely leads to highly infestation and yield reduction in cotton crop. Cotton is affected by number of insect pests including sucking and chewing types of insects. $\mathrm{CLCuD}$ is a causal agent of monopartite begomovirus which is transmitted through Bemisia tabaci, an insect vector and it belongs to genus Begomovirus, family Geminiviridae (ELNur, 1967; Awan et al., 2016, Raza et al., 2016). CLCuD has typical characteristic symptoms, curling of leaves, leaf enation, darkening and swelling of veins (Briddon and Markham, 2000). It is a monopartite begomovirus having DNA-A component which is required for DNA replication, insect transmission, and gene expression (Noueiry et al., 2000; Rybicki et al., 1994; Stanley, 1983). To produce characteristics symptoms Monopartite begomoviruses required single standard DNA betasatellite (Saunders et al., 2000; Briddon et al., 2001). The two types of satellites are referred to as alphasatellites and betasatellites, demonstrating two different types of small, half unit sized (in comparison to the viral genome), circular ssDNAs. The satellites have a role to host defense destruction, leading to enhanced virulence of the helper virus resulting in systemic infection and the production of severe disease symptoms. In at least one instance, an alphasatellite has been shown to down-modulate helper virus-beta satellite symptoms and reduced betasatellite accumulation in tomato plants (Idris et al.,2011). Due to great economic and commercial importance of cotton leaf curl disease, the study is planned to fulfill our objective to check diversity of DNA-A components of Begomovirus in Gossypium hirsutum L. through PCR. Screening of twenty lines/varietis under natural field conditions. The research work was based on the hypothesis that detecting the circular single stranded DNA molecule in relation with CLCuD may be helpful in respect to correct diagnosis and diversity among the CLCuD strains through Restriction Fragment Length Polymorphism (RFLP). Molecular techniques can be applied for this purpose in order to gain maximum success against CLCuD. Furthermore, it can be a protective strategy for the management of CLCuD at genomic level.

\section{MATERIALS AND METHODS}

Sample collection: Depending upon symptoms of cotton leaf curl disease such as thickening of veins, darkening of veins, curling of leaves and occasionally leaf enation, sampling was done from the newly emerging leaves because these contained more replicating virus

Genomic DNA extraction: DNA was extracted from the young leaves by using ( $2 \mathrm{X}$ CTAB) Cetyl Trimethyl Ammonium Bromides method as described by Doyle and Doyle (1990). Set the water bath at $65^{\circ} \mathrm{C}$ and $2 \mathrm{X}$ cetyl trimethyl ammonium bromides ( $2 \mathrm{X}$ CTAB) with $0.2 \% 2$ mercaptoethanol was preheated. Autoclaved pestle and mortar was used to grind the leaves in liquid nitrogen into fine powder. This powder was transferred to a $50 \mathrm{ml}$ tube and $15 \mathrm{ml}$ of hot $\left(65^{\circ} \mathrm{C}\right) 2 \mathrm{X} \mathrm{CTAB}$ was added to the tube. The paste was mix gently by capsizing the tube for several times and incubated at $65^{\circ} \mathrm{C}$ for 30 minutes. An equal volume of Chloroform-Isoamyl Alcohol (24:1 v/v) was added to form a suspension mixed gently by inverting the tube. Then the tubes were centrifuge at $9000 \mathrm{rpm}$ for 10 minutes. The supernatant was collected to a new tube and remaining chloroform was discarded. To precipitate the DNA, 0.6 volumes chilled isopropanol was add. Again centrifugation was done at 9000 rpm for 5 minutes and supernatant solution was discarded. The pellet was re-suspended in $50 \mu 1$ sterile distilled water (SDW). In the suspension RNase $5 \mu \mathrm{l}$ was added and incubated it at $37^{\circ} \mathrm{C}$ for 1 hour. An equal volume of Chloroform-Isoamyl Alcohol (24:1) was added and mixed gently. The eppendorf tubes were centrifuged at $13000 \mathrm{rpm}$ for 10 minutes and the supernatant was transferred into new autoclaved eppendorf tubes. In the mixture $1 / 10^{\text {th }}$ volume of $3 \mathrm{M}$ sodium acetate was added and slightly mixed. The DNA was precipitated with chilled absolute ethanol (2.5 volumes) and placed at $-20^{\circ} \mathrm{C}$ for 30 minutes. The samples were centrifuged at $13000 \mathrm{rpm}$ for 10 minutes, the supernatant was waste and the pellet was washed with $70 \%$ ethanol. The pellet was air dried and re-suspend in sterile distilled water (SDW) and stored at $-20^{\circ} \mathrm{C}$.

Preparation of agarose gel: Preparation of 1\% agarose gel was done for the running of total genomic DNA, PCR products. $1 \%$ agarose in $150 \mathrm{ml}$ of TBE buffer was added. This solution was boiled in oven at $100^{\circ} \mathrm{C}$ for 2 minutes. Solution was cooled at tolerable state and $2 \mu 1$ ethidium bromide was added. Combs were place in the gel plates and gel solution was poured on gel plate. Placed it for 20 minutes to solidify.

PCR from DNA dilution: For amplification of DNA, the optimum reagents were supplied by Fermentus. First of all dilutions for PCR were made as $1 \mu$ l of total genomic DNA solution into $100 \mu \mathrm{l}$ of double deionized water. For total reaction of $25 \mu \mathrm{l} \mathrm{PCR}$, these reagents were used template DNA $2.5 \mu 1$, dNTPs $0.5 \mu 1$, PCR buffer $10 \mathrm{X} 2.5 \mu 1, \mathrm{MgCl} 2$ $1.5 \mu 1$, primer I $0.5 \mu 1$, primer II $0.5 \mu 1$, Taq polymerase $0.3 \mu 1$, SDW 16.7 $\mu 1$. In three major steps of PCR, timing of denaturation $\left(94^{\circ} \mathrm{C}\right)$, annealing $\left(50-64^{\circ} \mathrm{C}\right)$ and extension $\left(72^{\circ} \mathrm{C}\right)$ were optimized according to requirements; typically 1minute, 1 minute and 3 minute per 1000 bases to amplify, respectively. 
PCR profile: In PCR profile nine steps were present on the screen of PCR machine. First was heat lid to $110^{\circ} \mathrm{C}$, then $94^{\circ} \mathrm{C}$ for 3 mints, after that start loop $30 \mathrm{X}$, then $94^{\circ} \mathrm{C}$ for 1 mints, in next step $50^{\circ} \mathrm{C}$ for 1 mints, then $72^{\circ} \mathrm{C}$ for $1: 30$ mints, after that Close loop, in end $72^{\circ} \mathrm{C}$ for 10 mints and in last step Store forever at $8^{\circ}$. Then $3 \mu \mathrm{l}$ of PCR product was run on Gel Electrophoresis for 45 minutes.

PCR-RFLP virus diversity analysis: DNA was extract from leaf samples by the CTAB method. Total DNA extract was suspended in sterile distilled water and kept at $-20^{\circ} \mathrm{C}$. A set of universal primers were used for PCR of DNA-A component of virus by universal primer Beg-01 (CCACGCGTCCGTG) [...GCTGCCCCATTCC] and Beg02 (CCACGCGTATGGGCT...Y) [CGAAGTTSASACG], which should be in model amplify genomes of all begomovirus (or DNA A genomic components), by standard protocols. PCR products were ethanol precipitated and immersed with restriction endonucleases Pst1 and EcoR1 selected for their ability to decide CLCuD-associated begomoviruses. Restriction digests were electrophoresed on $1 \%$ agarose gels tainted with ethidium bromide and photographed on a UV transilluminator.

\section{RESULTS}

The DNA-A components from CLCuV infected cotton plants were polymerized through PCR by using universal begomo 01 and begomo 02 primers.

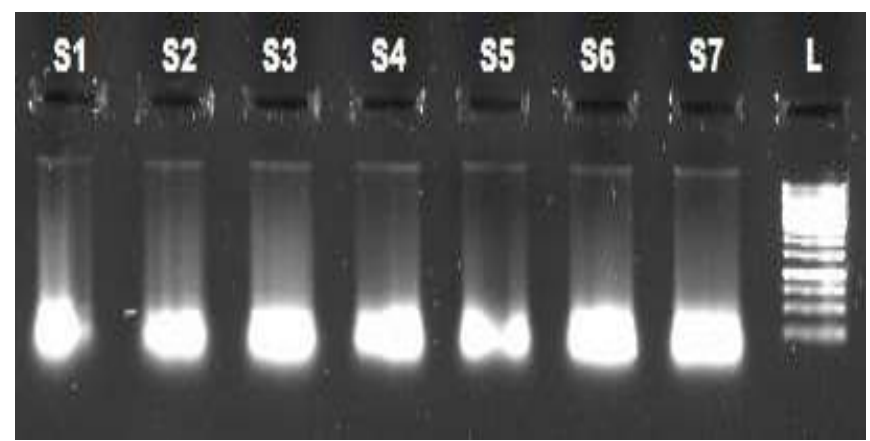

Figure 1. Genomic DNA extraction from different samples.

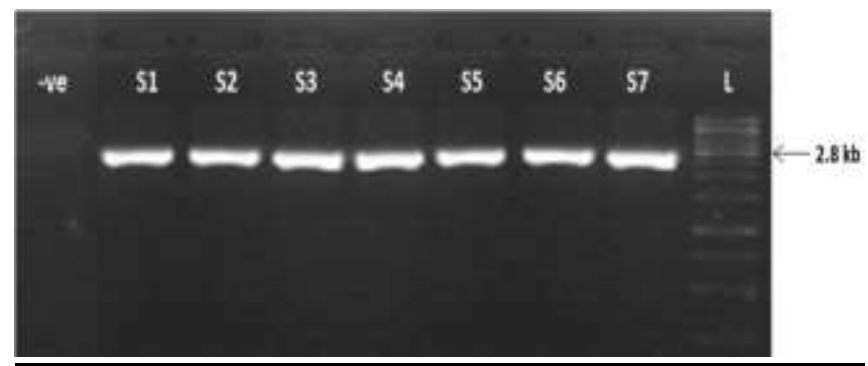

Figure 2. PCR of CLCuV infected cotton plants.
CATB method was used for isolation of total genomic DNA as explained. Seven samples were used for DNA isolation. Gel electrophoresis was used for DNA Confirmation all the samples show equal size as the size of DNA-A which is $2.8 \mathrm{~kb}$.

\section{Restriction fragment length polymorphism (RFLP):}

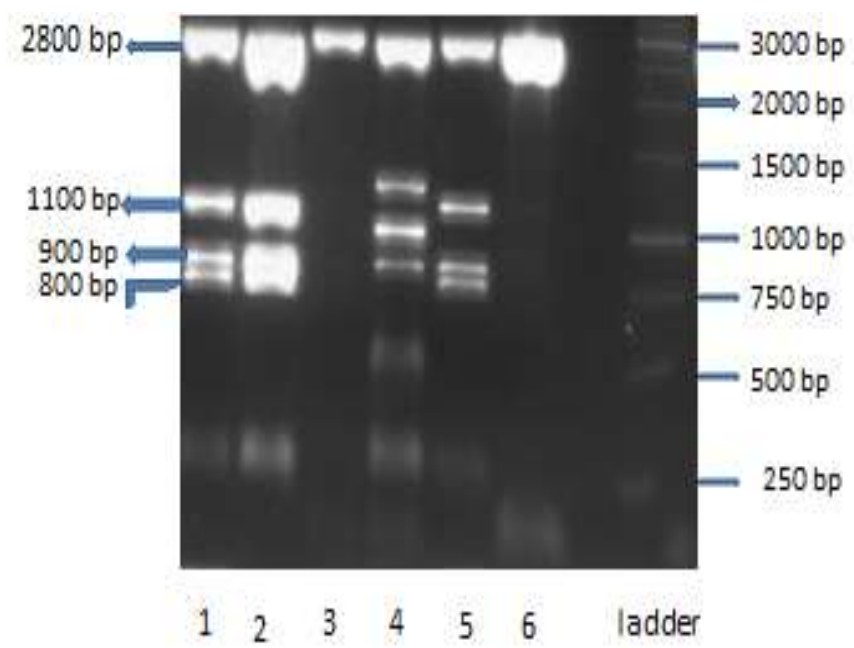

Figure 3. Plasmid was restricted with EcoRI and PstI and in combination with EcoRI and PstI.

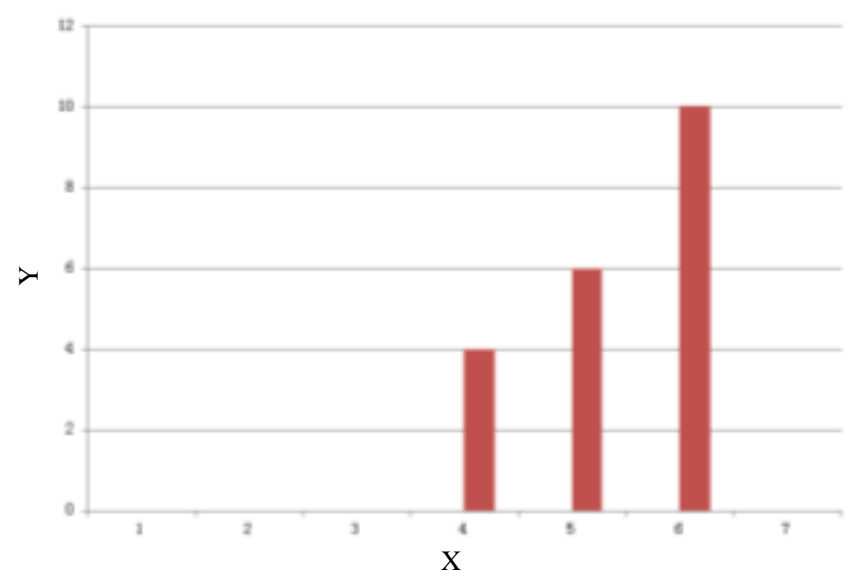

Figure 4. Screening of Twenty advanced lines/Varieties of cotton given below.

The residual viral titer evaluated through PCR and its value was compared with the visually observed symptoms to evaluate the plant response. All varieties showed disease symptoms. Susceptible varieties were FH-114. MNH-886, LALAZAR, MS-71, MS-289, FH-682, FH-900, Z-31, ALI AKBR-703 and N-112. Moreover, moderate susceptible varieties were FH-942, FH-142, MNH-86, CM-595, HUMA15 and ALI AKBR-905. However, moderate resistant varieties were FH-941, CM-595, ALI AKBR-905 and CA-12. 


\section{DISCUSSION}

CTAB method was used for DNA extraction from infected cotton samples explained by Doyle and Doyle (1990). Maximum DNA absorbance should be $260 \mathrm{~nm}$. 1.8 is pure DNA ratio and less than it means it had impurities. If ratio is greater than 2 it means it had phenol chloroform and it should be treated with ethanol. Kumar et al. (2010) revealed the maximum resemblance $(85 \%)$ of DNA-A sequence of two isolates. The $1^{\text {st }}$ isolate CLCuV-SG01 showed maximum sequence similarity with cotton leaf curl rajasthan virus (CLCuRV) and $2^{\text {nd }}$ isolate CLCuV-SG02 showed maximum resemblance with CLCuV from Pakistan. Amrao et al. (2010) reported that a recombinant and distorted begomovirus which break resistance in cotton, $\mathrm{CLCuBuV}$, it contains sequences derived from cotton leaf curl multan virus (CLCuMV) and CLCuKV. TrAP (transcriptional activator protein) gene is missing in $\mathrm{CLCuBuV}$ due to distortion.

DNA-A component of begomoviruses contains either five or six ORFs in both directions that encode $10 \mathrm{kDa}$. The virion strand consists of a forecast hairpin structure containing unspoiled (between geminiviruses) In the loop and interons Nona nucleotide (TAATATTAC) sequence is present. Proteins are required for functioning which are (TrAP) transcriptional activator protein, (CP) Coat protein, (REn) replication enhancer protein and (Rep) replication associated protein. These all genes control host and viral gene expression. In old world, AV2 and AC4 protein are involved in control of viral moment and cell cycle found in all begomoviruses. AV2 protein is absent in the new world. DNA-B component of bipartite begomovirus encode (NSP) nuclear shuttle protein and (MP) movement protein, which help virus to move between and within the cell. Virus lives due to difference in gene functions and acceptance as related with TYLCSV, TYLCV and ToLCV In the absence of DNA B component (Briddon and Stanley, 2006). Despite identification of vector as well as virus with in the middle 1990 's the actual etiology associated with CLCuD continued to be not clear. In 2000 symptoms introduced by CLCuMV infectious clone were same (Briddon et al., 2000). During this effort DNA component was detached which was associated with $\mathrm{CLCuD}$, known as alphasatellites. Alphasatellites can replicate independently in host cells and are single-stranded DNA-A molecule. Nanoviruses and alphasatellites shows similarity due to rep protein (Mansoor et al., 1999). Proper role of alphasatellites is unknown, only they are considered to maintain infection in susceptible plants which does not kill the host (Mansoor et al., 2003).

Every year due to mutation in virus the complex of CLCuD was checked, 07 infected samples of cotton were collected from field area of Plant Pathology University of Agriculture, Faisalabad having characteristic symptoms of leaf enation, leaf curling and vein thickening. DNA was isolated from these 7 samples. PCR amplification was observed in 7 samples. Each sample shows equal to $2800 \mathrm{bp}$ which was size of DNA-A component, In silicostudies were done for the comparison of original plasmid with already known sequences of different viruses. Plasmid was restricted with EcoRI and PstI and in combination with EcoRI and PstI. EcoRI restricted plasmid into two fragments of $900 \mathrm{bp}$ and $1300 \mathrm{bp}$. Some part of insert remained attached with vector which was $600 \mathrm{bp}$ that's why vector showed little upper on gel electrophoresis. PstI restricted plasmid with in two fragments $1200 \mathrm{bp}$ and $1600 \mathrm{bp}$ size which is exact equals DNA-A component while double restriction with EcoRI and PstI gave 4 bands of insert. These analysis revealed that CLCuMV is associated with CLCuD. All varieties showed disease symptoms. Susceptible varieties were FH-114, MNH886, LALAZAR, MS-71, MS-289, FH-682, FH-900, Z-31, ALI AKBR-703 and N-112. Moreover, moderate susceptible varieties were FH-942, FH-142, MNH-86, CM-595, HUMA15 and ALI AKBR-905. However, moderate resistant varieties were FH-941, CM-595, ALI AKBR-905 and CA-12.

Conclusions: Out of twenty lines/varieties there was no line found to exhibit immunity against CLCuD, no highly resistant, no resistant. Ten varieties found susceptible, six varieties found moderately susceptible, four varieties found moderate resistant Plasmid was restricted with EcoRI and PstI and in combination with EcoRI and PstI. EcoRI restricted plasmid into two fragments of $900 \mathrm{bp}$ and $1300 \mathrm{bp}$. Some part of insert remained attached with vector which was $600 \mathrm{bp}$ that's why vector showed little upper on gel electrophoresis. PstI restricted plasmid with in two fragments $1200 \mathrm{bp}$ and 1600 bp size which is exact equals DNA-A component while double restriction with EcoRI and PstI gave 4 bands of insert.

Acknowledgement: I am grateful for the support of CABB in conducting this research. I am very grateful to my supervisor Prof. Dr. Muhammad Aslam Khan for critical reading of the manuscript, Dr. Muhammad Mubin of $\mathrm{CABB}$ and Dr. Luqman Amrao for their support and encouragement.

\section{REFERENCES}

Amrao, L., I. Amin, S. Shahid, R.W. Bridden and S. Mansoor. 2010. Cotton leaf curl disease in resistant cotton in associated with a single begomovirus that lacks an intact transcriptional activator protein. Virus . Res.152:153-63.

Awan, M.F., A. Ali, A. Muzaffar, M.A. Abbas, A.Q. Rao, Z. Qamar, S.J. Butt, G.A. Khan, B. Rashid, I.A. Nasir and T. Husnain. 2016. Transgenic cotton: harboring broad term resistance against insect and weeds through incorporation of CEMB double Bt and cp4EPSPS genes. Pak. J. Agri. Sci. 53:501-505.

Briddon, R.W. and J. Stanley. 2006. Sub-viral agents associated with plant-infecting single-stranded DNA viruses. Virology. 344:198-210. 
Briddon, R.W. and P.G. Markham. 2000. Cotton leaf curl virus disease. Virus Res. 71:151-59.

Briddon, R.W. and P.G. Markham. 2000. Cotton leaf curl virus disease. Virus Res. 71:151-59.

Briddon, R.W., S. Mansoor, I.D. Bedford, M.S. Pinner, K. Saunders, J. Stanley, Y. Zafar, K.A. Malik and P.G. Markham. 2001. Identification of DNA components required for induction of cotton leaf curl disease. Virology. 285:234-243.

Bruinsma, J. 2003. World Agriculture: Towards 2015/2030: An FAO Perspective. Earthscan Publication Limited, London.

Bruinsma, J. 2003. World Agriculture: Towards 2015/2030. An FAO Perspective. Earthscan Division (Economic Wing), Islamabad, Pakistan.

Farooq, A., J. Farooq, A. Mahmood, A. Shakeel, A. Rehman, A. Batool, M. Riaz, M.T.H. Shahid and S. Mehboob. 2011. An overview of cotton leaf curl virus disease (CLCuD) a serious threat to cotton productivity. AJCS. 5:1823-1831.

Idris, A.M., M.S. shahid, R.W. Briddon, A.J. Khan, J.K. Zhu and J.K. Brown. 2011. An unusual Alphasatellite associated with monopartite begomoviruses attenuates symptoms and reduces betasatellite accumulation. J. Gen. Virol. 92:706-17.

Kirthi, N., C.G.P. Priyadarshini, P. Sharma, S.P. Maiya, V. Hemalatha, P. Sivaraman, P. Dhawan, N. Rishi and H.S. Savithri. 2004. Genetic variability of begomoviruses associated with cotton leaf curl disease originating from India. Arch. Virol. 149:2047-2057.

Kumar, A., J. Kumar and J.A. Khan. 2010. Sequence characterization of cotton leaf curl virus Rajasthan: Phylogenetic relationship with other members of geminiviruses and detection of recombination. Virus Genes 40:282-289.

Mansoor, S., I. Amin, S. Iram, M. Hussain, Y. Zafar, K.A. Malik and R.W. Briddon. 2003. Breakdown of resistance in cotton to cotton leaf curl disease in Pakistan. Plant Pathol.52:784.
Mansoor, S., S.H. Khan, A. Bashir, M. Saeed, Y. Zafar, K.A. Malik, R.W. Briddon, J. Stanley and P.G. Markham. 1999. Identification of a novel circular single-stranded DNA associated with cotton leaf curl disease in Pakistan. Virology. 259:190-199.

Noueiry, A.O., W.J. Lucas and R.L. Gilbertson. 1994. Two proteins of a plant DNA virus coordinate nuclear and plasmodesmal transport. Cell. 76:925-932.

Padidam, M., S. Sawyer and C.M. Fauquet.1999. Possible emergence of new geminiviruses by frequent recombination. Virology 265:218-225.

Raza, M.M., M.A. Khan, M. Yaseen, A. Munawar and Z. Sabir. 2016. Exploring the potential of multivariate analysis to study the impact of cotton leaf curl disease on yield traits. Pak. J. Agri. Sci. 53:507-512.

Rybicki, E.P., R.W. Briddon, J.E. Brown, C.M. Fauquet, D.P. Maxwell, B.D. Harrison, P.G. Markham, D.M. Bisaro, D. Robinson and J. Stanley. 2000. Geminiviridae- Virus Taxonomy: Seventh Report on the International Committee on Taxonomy of Viruses. Academic Press, San Diego. pp.285-97.

Saunders, K., I.D. Bedford, R.W. Briddon, P.G. Markham, S.M. Wong and J. Stanley. 2000. A novel virus complex causes Ageratum yellow vein disease. Proc. Natl. Acad. Sci. 97:6890-6895.

Seal, S.E., F. van den Bosch and M.J. Jeger. 2006. Factors influencing begomovirus evolution and their increasing global significance: Implication for sustainable control. Crit. Rev. Pl. Sci. 25:23-46.

Stanley, J. 1983. Infectivity of the cloned geminivirus genome requires sequences from bothDNAs. Nature 305:643645.

Stanley, J., D.M. Bisaro, R.W. Briddon, J.K. Brown, C.M. Fauquet, B.D. Harrison, E.P. Rybicki and D.C. Stenger. 2005. Geminiviridae. In: C.M. Fauquet, M.A. Mayo, J. Maniloff, U. Desselberger and L.A.Ball (eds.), Virus Taxonomy, VIII $^{\text {th }}$ Report of the ICTV. Elsevier/Academic Press, London. pp.301-326. 